\title{
Editorial
}

\section{Asian emerging multinationals and the dynamics of institutions and networks}

\author{
Pavida Pananond ${ }^{\mathrm{a}, *}$ and Axèle Giroud ${ }^{\mathrm{b}}$ \\ ${ }^{\mathrm{a}}$ Thammasat Business School, Thammasat University, Bangkok, Thailand. \\ E-mail: pavida@tbs.tu.ac.th \\ ${ }^{\mathrm{b}}$ Alliance Manchester Business School, University of Manchester, Manchester, UK. \\ *Corresponding author.
}

\begin{abstract}
Multinationals from developing Asia originate from highly diverse countries. Their rise challenges various existing theoretical concepts on the internationalisation of MNEs, their institutional background and context-specific features. We suggest here that the role of institutions and firm networks must be better conceptualised to reflect the internationalisation of MNEs from developing Asia. In particular, we propose that a key driver for internationalisation is explained not just by social networks but also by dynamic evolution in network relationships within industry value chains. We also argue, given the context of increased regional integration, that institutional boundaries should be expanded from country to region.
\end{abstract}

Asian Business \& Management (2016) 15, 255-263. doi:10.1057/s41291-016-0010-2; published online 31 August 2016

Keywords: developing Asia; emerging multinationals; internationalisation; ownership advantages; institutions; business networks

\section{Recent trends}

The recent surge in outward foreign direct investment (FDI) from emerging economies has been largely dominated by Asia, particularly East Asia (UNCTAD, 2016). Global FDI flows are undertaken more and more by firms from emerging economies. This shift brings about a rising set of firms that are becoming global players and strong competitors to the traditional multinational enterprises (MNEs) that originate from advanced economies. Firms from Asia have been at the forefront of this momentum, making their presence felt in a wide variety of industries from basic resource-based sectors like food and agribusiness to more sophisticated areas such as telecommunications and transportation services. 
The increasing significance of this new set of global players has triggered academic interest and led to growing debates on emerging-market multinational enterprises (EMNEs). Viewed through the theoretical lens of international-business literature, this growing body of work has shed light on the rise of EMNEs from a variety of emerging economies, particularly the larger ones such as China, India, Brazil, Mexico and Russia. Focusing on developing Asia, however, a shift is taking place, as players from smaller economies increase their global outreach. Between 2006 and 2014, the proportion of MNEs from China and India declined from more than two-thirds to under half of the ' 100 Global Challengers' (emerging-economybased firms that are rapidly growing their global footprint: BCG, 2014). Firms from smaller Asian economies, particularly those in Southeast Asia, are joining the list.

Given these recent trends, academic studies may not have sufficiently reflected this diversity. Reviewing literature on the international activities of EMNEs, Jormanainen and Koveshnikov (2012) highlighted how the overwhelming majority of research articles in international business and management journals were based around firms from China and India. Such dominant representation may lead to conclusions and implications that are more specific to the unique characteristics of those countries and may not apply to firms from smaller economies. This may have implications in terms of theoretical understanding of EMNE internationalisation in general, and that of firms from Asia in particular. Asia is not a homogenous region, and developing Asia is much more diverse than what may be represented by China and India. This special issue therefore answers calls for more attention to context (Meyer and Peng, 2016; Colpan and Hikino, 2013) and provides an opportunity to consider research on the internationalisation of firms from developing Asia in a broader geographical scope.

\section{Overview of relevant studies and theoretical insights on internationalisation of firms from developing Asia}

The determinants behind Asian firms' international expansion continue to be central in academic debate (Colpan and Hikino, 2013) Firstly, East Asian firms' outward FDI is growing rapidly; it represents a large share of emerging-market outward FDI, and as a result these firms' role in shaping the global competitive landscape is significant. Secondly, the antecedents, motivations and patterns of many East Asian firms' internationalisation continue to challenge existing theoretical assumptions that MNEs internationalise in order to exploit overseas ownership advantages built in home conditions.

On the one hand, many emerging MNEs internationalise with the objective of building rather than exploiting their own ownership advantages, with asset-seeking motives prevailing in certain overseas markets, and an accelerated internationalisation pattern (Luo and Tung, 2007; Mathews, 2006) challenging assumptions of

(C) 2016 Macmillan Publishers Ltd. 1472-4782 Asian Business \& Management Vol. 15, 4, 255-263 
the gradual process first described by the Uppsala Model (Johanson and Vahlne, 1977). There is also increasing evidence that the internationalisation pattern of a number of emerging multinationals is closely linked to past and current networks (Meyer and Thaijongrak, 2013). Additional insights are needed to fully understand how successful these firms are in strengthening their own competences through this rapid internationalisation process, in particular through their asset-seeking investments, and how learning occurs through the implementation of such strategies (Rugman and Li, 2007; Hennart, 2012; Ghauri and Santangelo, 2012).

On the other hand, the literature points to the uniqueness of home-locational advantages (or disadvantages) driving firms to engage in global activities, particularly in Asia, where business systems present distinct features compared to both those of the West and those of each other (Witt and Redding, 2013). This raises the question as to how the home-institutional context of firms from developing Asia differs from that of developed-country firms, and also whether existing conceptualisation can be drawn from such differences; and if so, whether and how institutional considerations reflect and explain internationalisation of firms from this part of the world.

As a result, we suggest that the uniqueness of institutions and firm networks need to be better conceptualised to understand the context of internationalisation of MNEs from developing Asia.

\section{Role of institutions: From country to region}

The international-business literature has long accepted that MNE activities are affected by and have an impact on different institutional regimes (Meyer and Peng, 2016), particularly when analysing emerging MNEs (Cuervo-Cazurra and Ramamurti, 2014; Giroud, 2014).

Within and across countries, institutions jointly interact to influence the development of local firms, shaping firm organisation, strategy and structure, explaining why specific types of firms may prevail in one country setting (e.g. family firms or state-owned firms). Institutions influence the capacity of firms, both foreign and local, to interact, as well as the relative transaction and coordination costs of production and innovation. Moreover, particularly in developing countries, the role of the State is pivotal in terms of coordinating economic development and in its relationship to the private sector. Subsequently, various combinations of transactions, resources and patterns of governance affect the development of ownership advantages among local firms in the home market, impacting on firms' drive and potential to internationalise (Witt and Lewin, 2007).

As a result, there has been rising interest in the role of institutions in explaining how home institutions impact upon emerging MNEs' competitiveness. Yet little is known about the means through which home institutions drive internationalisation 
in firms from developing Asia. Some studies suggest that an institutional void will prompt internationalisation, or that institutional similarity provides an advantage for developing-country firms to invest in other developing countries, while other studies point to the pivotal role of government (e.g. through direct influence over the internationalisation of state-owned enterprises, or through policies incentivising outward FDI) (Luo et al, 2010; Cuervo-Cazurra and Ramamurti, 2014). Few studies focus on the uniqueness of Asian local institutional contexts and how they have been upheld (Taube, 2015), and fewer still on how the relationship functions between home institutions, firms' ownership advantages and internationalisation.

For firms from developing Asia, we argue that additional institutional considerations must be integrated into studies of firm internationalisation. In these environments, home institutions matter in explaining how and why firms move from export-led to overseas-expansion strategies, choosing to internationalise and establish operations overseas even if they possess few ownership advantages.

There are three main reasons why home-country institutions may play a role in facilitating this process. Firstly, countries in developing Asia are well integrated into global value chains, and local firms have long been active in the export process, leveraging their potential for upgrading initially through exports (Pananond, 2013). Secondly, firms can derive competitiveness from home-country comparative advantages (e.g. in the resource-based sector) rather than through ownership advantages (e.g. proprietary assets such as technology, marketing, brand name, capital, access to finance, price efficiencies, economies of scale and scope, or managerial expertise) (Luo and Tung, 2007; Rugman et al, 2014). Thirdly, beyond home comparative advantages, both global and regional institutional settings influence the potential and propensity of firms to internationalise, and their internationalisation strategy (Youngwoo et al, 2014); in Southeast Asia, the ASEAN regional institutional context has provided a platform for firms in the region to benefit from enlarged markets, creating the incentive to internationalise on a regional basis.

In summary, we suggest that developing Asia presents a set of unique institutional settings in which business is conducted, and in order to refine our knowledge on firms' internationalisation, these need to be better understood and integrated into theoretical and practical analysis.

\section{Role of networks: From static to dynamic}

Numerous studies provide insights into the role and nature of business networks in Asia, and how different types of networks and networking capabilities contribute to the competitive advantages of Asian firms. Focusing on EMNEs from developing Asia, we argue that the complex structure of network relationships in which these firms are engaged prior to as well as during their internationalisation provides a rich 
context to explore in more detail how different types of network impact on internationalisation. In particular, this offers an opportunity to explore how the fragmentation of business activities across geographical locations (the global value chain) shapes network relationships among firms and how their international growth becomes increasingly relevant in today's global economy.

Early studies on the role of networks and the internationalisation of firms from Asia tended to view networks as a cultural trait in Asian societies. The general consensus was that the personal and ethnic networks commonly present in Asian business contexts constitute social capital that could serve as key resources in the domestic development and international expansion of Asian firms (Pananond and Zeithaml, 1998; Mathews, 2006; Peng and Zhou, 2005; Witt and Redding, 2013; Lin et al, 2014). From the socially embedded view of the firm (Granovetter, 1985), personal and ethnic network relationships were considered as external resources into which firms could tap to enhance their own shortage of competitive resources. Social networks such as ethnic and diaspora ties (Liu and Giroud, 2016) have been considered crucial in the early internationalisation of Asian firms, especially among Chinese and Indian companies, as they could link investing firms to overseas knowledge clusters, serve as sources for talents and internal capital, and as markets (Contractor, 2013).

Yet, as Asian MNEs advance their internationalisation, the complexity of network relationships intensifies. While some forms of network relationships may continue, their scope could be diminish (Hennart, 2015). On the other hand, the more integrated nature of global economic activities, particularly in the value chains of global industries, increases layers of business relationships among firms from developed and developing countries. More specifically, the link between value-chain integration, upgrading potential and how some firms benefit from internationalisation has not so far been clearly theoretically established. As firms from developing Asia deepen their international activities and broaden their geographical footprints, the global valuechain (GVC) perspective that considers these chains as networks that link different types of firms across geographical locations becomes more relevant to the growth and development of firms (Sturgeon and Gereffi, 2009), and the fine slicing of firms' economic activities and specificities of the segments in which firms take part is likely to influence their motives for internationalisation (Giroud and Mirza, 2015).

Typically, firms from emerging economies are integrated into GVCs as manufacturers and suppliers to lead firms from advanced economies, in order to deliver final products to customers in those advanced economies. However, rapid and aggressive internationalisation of Asian firms through mergers and acquisitions has altered the power dynamics within many GVCs. As GVCs become a structure encompassing various types of players with different goals towards internationalisation, more work can be done to shed light on the link between value-chain integration, upgrading potentials and the changing dynamics among chain participants. 
Similarly, rapid and aggressive internationalisation of firms from developing Asia, especially in more advanced economies, challenges conventional assumptions concerning headquarters-subsidiary relationships. Unlike asset-exploitation internationalisation, in which headquarters exert more control and power, strategic asset-seeking firms from developing Asia may exercise power differently, especially over subsidiaries in more advanced economies. The dynamics of power-play among actors in the value chain and the interactive integration of subsidiaries from developed economies to headquarters in Asian emerging economies are among the factors that lead to a new normal for the context of internationalisation by Asian firms, hence opening up areas for further studies.

In summary, we suggest that, in the context of developing Asia, a key driver for internationalisation is explained not solely by the static existence of social networks but also by the dynamic evolution in network relationships built up when operating within their own home country (i.e. through export and GVCs), and the potential benefits to be drawn from international growth (i.e. through various modes of entry, such as M\&As).

\section{Papers in this special issue}

Addressing the above issues and building on existing debates in the international and comparative business literature (Colpan and Hikino, 2013), this special issue adds to existing knowledge on internationalisation in Asia by focusing in particular on the role of institutions and networks. Selected from papers presented at the Euro-Asia Management Studies Association 2014 Conference on 'Regional Integration, Value Chains and Multinational Firms', the three papers address questions on institutions and networks from different angles.

In their paper 'Firm-specific, country-specific and region-specific competitive advantages: The case of emerging-economy MNEs - Thailand', Beleska-Spasova, Loykulnanta and Nguyen build on the traditional distinction between firm-specific advantages (FSAs) and country-specific advantages (CSAs) by advancing a theoretical concept of regional-specific advantages (RSAs). The authors argue that increasing levels of regional economic integration - in Southeast Asia in their case - create regional competitive advantages beyond firm-specific FSAs and countryfocused CSAs. These regional advantages, or RSAs, arise from the geographical, cultural, administrative and economic proximity of countries within the region. These benefits can accrue to firms and allow them to exploit not only their FSAs and home-country CSAs but also regional RSAs. Extending from the double- and dual-double-diamond models, the paper extends the empirical investigation of international competitiveness from a country-level to a regional-level perspective.

By pointing out how Thai firms derive advantages more from country-specific factors than firm-specific ones, and how they can also draw regional-specific

(C) 2016 Macmillan Publishers Ltd. 1472-4782 Asian Business \& Management Vol. 15, 4, 255-263 
advantages from the increasingly integrated Southeast Asian region, Beleska-Spasova et al, demonstrate that supra-national institutions, derived from moves towards stronger regional economic integration, are critical for Thai firms' competitiveness. This paper therefore contributes to the contemporary debate on the role of regional institutions, economic benefits to member countries and firms' specific advantages.

The paper by Pananond, 'From servant to master: Power repositioning of emerging-market companies in global value chains', provides further insights into Thai emerging multinationals. The author establishes that supplier firms that start modestly as producers and exporters in the value chain of global industries can use internationalisation at regional and global levels to improve their power positioning within the value chain. Complementing the upgrading-through-technological capabilities view, the author proposes a power-repositioning argument, whereby local firms improve their power position through taking more control of the chain as part of the upgrading process. This process enables local firms to break away from low value-added positions within the value chain and exert more power within the governance structure of global value chains. Based on a case study of a Thai firm that had a modest start as a contract manufacturer but rose to become the world's largest canned-tuna company, Pananond's paper demonstrates how the Thai Union group used international expansion towards downstream activities to enhance its power position in the globally integrated buyer-driven seafood industry. A main contribution of this paper is to emphasise the need for emerging-market supplier firms, which typically occupy low value-added positions in GVCs, to be more pro-active and to use international expansion as a way to counterbalance the power dynamics of advanced-economy-based lead firms.

Zheng, in 'Aggressive acquirers, laidback owners? Organisational dynamics of subsidiary integration in Chinese MNCs', also adds to the debate on emerging multinationals and power dynamics by investigating the power relations underpinning subsidiary integration between Chinese MNEs and their subsidiaries in more advanced economies. Noting that Chinese MNEs tend to be 'aggressive' in crossborder acquisition, yet 'laidback' in consolidating overseas subsidiaries based in more developed economies, the author argues that power struggles in MNE integration of subsidiaries are characterised by how actors mobilise sources of power and how they enact power. The paper contributes by demonstrating how Chinese MNEs engage in mergers and acquisitions to gain access to strategic assets, but in the process can encounter resistance from overseas subsidiaries due to their lack of strong ownership advantages and sophisticated managerial expertise in managing international subsidiaries. The author affirms that managerial behaviours in MNEs and subsidiaries are partly shaped by home- and host-country institutions. Thus, for a successful process of subsidiary integration, developing-country multinationals - in this case Chinese firms - must carefully balance and assess power relationships, their own ownership advantages and local institutional considerations. 


\section{About the Authors}

Pavida Pananond is Associate Professor of International Business at Thammasat Business School, Thammasat University, Thailand. Her research focuses on the internationalisation of firms and global value chains, particularly in emergingmarket multinationals. Pavida is Vice-President of the Euro-Asia Management Studies Association (EAMSA), and editorial board-member on several academic journals. She has published in academic journals such as Management International Review, Journal of International Management, Asian Business \& Management and Asia Pacific Journal of Management. Her commentaries and opinion articles also appear in local and international media, including Bangkok Post, Nikkei Asian Review, The Economist and the Financial Times.

Axèle Giroud is Professor of International Business, and Director of the MSc in International Business and Management with the Alliance Manchester Business School, University of Manchester, and Visiting Professor with the University of Gothenburg, Sweden. Her main research interests are multinational enterprises' economic and social impact in host countries, inter- and intra-firm linkages, technology and knowledge transfers, and international strategy. She sits on the editorial board of several academic journals and has published extensively in journals such as Journal of World Business, Journal of International Marketing, Asian Business \& Management, International Business Review, Management International Review and World Development.

\section{References}

BCG (Boston Consulting Group) (2014) BCG Global Challengers: Redefining Global Competitive Dynamics. Boston: Boston Consulting Group.

Colpan, A. and Hikino, T. (2013) Internationalization of East Asian Firms. Asian Business \& Management 12(1): 1-13.

Contractor, F.J. (2013) Punching above their weight: The sources of competitive advantage for emerging-market multinationals. International Journal of Emerging Markets 8(4): 304-328.

Cuervo-Cazurra, A. and Ramamurti, R. (2014) Understanding Multinationals from Emerging Markets. Cambridge: Cambridge University Press.

Ghauri, P. and Santangelo, G. (2012) Multinationals and the changing rules of competition: New challenges for international business research. Management International Review 52(2): 145-154.

Giroud, A. and Mirza, H. (2015) Refining FDI motivations by integrating global value chains' considerations. Multinational Business Review 23(1): 67-76.

Giroud, A. (2014) Multinational enterprises in Asian business systems. In G. Redding and M. Witt (eds.) Oxford Handbook of Asian Business Systems. Oxford, Oxford University Press, pp.441-464.

Granovetter, M. (1985) Economic action and social structure: The problem of embeddedness. American Journal of Sociology 91(3): 481-510. 
Hennart, J-F. (2012) Emerging-market multinationals and the theory of the multinational enterprise. Global Strategy Journal 33(2): 41-55.

Hennart, J-F. (2015) Leveraging Asian institutions to deepen theory: A transaction-cost perspective on relational governance. Asian Business \& Management 14(4): 257-282.

Johanson, J. and Vahlne, J-E. (1977) The international process of the firm: A model of knowledge development and increasing foreign market commitments. Journal of International Business Studies 8(1): 23-32.

Jormanainen, I. and Koveshnikov, A. (2012) International activities of emerging-market firms: a critical assessment of research in top international management journals. Management International Review 52(5): 691-725.

Lin, Y-H., Chen, C-J. and Lin, B-W. (2014) The roles of political and business ties in new ventures: Evidence from China. Asian Business \& Management 13(5): 411-440.

Liu, X. and Giroud, A. (2016) International knowledge flows in the context of emerging-economy MNEs and increasing global mobility. International Business Review 25(1): 125-129.

Luo, Y. and Tung, R.L. (2007) International expansion of emerging-market enterprises: A springboard perspective. Journal of International Business Studies 38(4): 481-498.

Luo, Y., Xue, Q. and Han, B. (2010) How emerging-market governments promote outward FDI: Experience from China. Journal of World Business 45(1): 68-79.

Mathews, J.A. (2006) Dragon multinationals: New players in $21^{\text {st }}$-century globalization. Asia Pacific Journal of Management 23(1): 5-27.

Meyer, K.E. and Peng, M.W. (2016) Theoretical foundations of emerging-economy business research. Journal of International Business Studies 47(1): 3-22.

Meyer, K.E. and Thaijongrak, O. (2013) The dynamics of emerging-economy MNEs: How the internationalisation-process model can guide future research. Asia Pacific Journal of Management 30(4): 1125-1153.

Pananond, P. (2013) Moving along the value chain: Emerging Thai multinationals in globally integrated industries. Asian Business \& Management 12(1): 85-114.

Pananond, P. and Zeithaml, C. (1998) The international expansion process of MNEs from developing countries: A case study of Thailand's CP Group. Asia Pacific Journal of Management 15(2): 163-184.

Peng, M.W. and Zhou, J.Q. (2005) How network strategies and institutional transitions evolve in Asia. Asia Pacific Journal of Management 22(4): 321-336.

Rugman, A. and Li, J. (2007) Will China's multinationals succeed globally or regionally? European Management Journal 25(5): 333-343.

Rugman, A., Nguyen, Quyen T.K. and Wei, Z. (2014) Chinese multinationals and public policy. International Journal of Emerging Markets 9(2): 205-215.

Sturgeon, T. and Gereffi, G. (2009) Measuring success in the global economy: international trade, industrial upgrading, and business function outsourcing in global value chains. Transnational Corporations 18(2): 1-35.

Taube, M. (2015) Institutional idiosyncrasies and alternative ways of doing business: What can we learn from East Asia? Asian Business \& Management 14(4): 251-256.

UNCTAD (United Nations Conference on Trade and Development) (2016) World Investment Report 2016. Investor Nationality: Policy Challenges. Geneva: United Nations.

Witt, M. and Lewin, A. (2007) Outward foreign direct investment as escape response to home-country institutional constraints. Journal of International Business Studies 38(4): 579-594.

Witt, M., and Redding, G. (2013) Asian business systems: institutional comparison, clusters and implications for varieties of capitalism and business systems theory. Socio-Economic Review 11(2): 265-300.

Youngwoo, L., Hemmert, M. and Kim, J. (2014) What drives the international ownership strategies of Chinese firms? The role of distance and home-country institutional factors in outward acquisitions. Asian Business \& Management 13(3): 197-225.

(ㄷ) 2016 Macmillan Publishers Ltd. 1472-4782 Asian Business \& Management Vol. 15, 4, 255-263 